\title{
Enablers of hybrid warfare: The Bulgarian case
}

\author{
Boyan Hadzhiev \\ Department of International Relations, \\ University of National and World Economy, \\ Bulgaria \\ bhadzhiev@,unwe.bg
}

\begin{abstract}
Russian actions in the Crimea since 2014 have increased Central and Eastern European countries concerns and strengthened their fears of becoming the next target of hybrid attacks. The common understanding of hybrid war as such is usually related to the ambiguous boundaries between peace and war. But this view is more about the reluctance of political leaders to recognize that hybrid warfare in its essence is a war with limited political aims carried out using a variety of military and non-military means. As in any war, the strategy of this warfare aims to foster the sense of insecurity and uncertainty in the opponent. Disinformation, subversion, demoralization and division in society, political corruption, provocations and threats are some of the key tools that are being applied with different success in the hybrid warfare. The paper presents a theoretical model consisting of three groups of factors (socio-historical, governmental and international) that create an appropriate environment for conducting a hybrid warfare. Taken together, these prerequisites allow the assessment of the degree of vulnerability to hybrid threats. In Bulgaria, the ongoing debate about Russia's role is developing in the context of the alleged hybrid war that Moscow is conducting in the country. The presented model is applied to the case of Bulgaria in order to show the practical potential of Russian hybrid aggression in this country.
\end{abstract}

Keywords: hybrid warfare, national security, Bulgaria, Russia.

JEL Classification: H56, F51, D74

\section{INTRODUCTION}

Hybrid warfare is not a new phenomenon, but technological revolution has increased the opportunities for and the intensity of implementing various instruments and tactics associated with it. This form of warfare is a suitable strategy for certain category of countries characterized by their global ambitions but insufficient capabilities for global leadership. The secrecy of a hybrid strategy allows the achievement of key 
(geo)political goals while avoiding open and direct war. That is why it is necessary to analyze the enablers for successful implementation of, and the victim state's vulnerabilities to a hybrid warfare.

Following the Russian-Ukrainian conflict for the Crimea and Eastern Ukraine, and the US presidential elections many analysis and assessments of the Kremlin's hybrid war appeared in the public space. Crimea's annexation has increased the concerns of Central and Eastern European countries and has strengthened their fears of becoming the next target of hybrid attacks. This situation has prepared grounds for interpreting different events through the prism of potential hybrid actions of Moscow. Today hybrid war is being used by various global and regional powers, not just by Russia, but the Ukrainian conflict has made Moscow's behavior the key symbol of using this strategy. Whether cultural, historical matters, national security, diplomacy and even sports are involved, almost every activity/inactivity of the Russian Federation is evaluated (sometimes even paranoidly) by its opponents as an element of a wider hybrid strategy. This trend hasn't bypassed Bulgaria. This is the reason why the current analysis focuses on the alleged Kremlin's hybrid warfare and on assessing whether it is a reality or rather a fiction. The analysis of the Bulgarian case outlines the enablers in implementation of the hybrid warfare strategy and contributes to the understanding of its practical manifestations.

In Bulgaria, the ongoing debate about Russia's role is developing in the context of the alleged hybrid war that Moscow is conducting in the country. Disputes in Bulgarian society are increasing, and Russia's role and intentions continue to be questioned, thus leading to a vast public conflict that has divided the Bulgarian society sharply. The lessons of Ukraine, as well as the intensification of the opposition between NATO and Russia, enhance the focus on the threat of conducting a hybrid war within Bulgarian borders. There are enough preconditions for that, and the ambiguity surrounding the nature and manifestations of the hybrid warfare provide fertile ground for debates and fears.

\section{LITERATURE REVIEW - HYBRID WAFARE IS IT A NEW CONCEPT?}

Since 2005, the hybrid war has become a concept, which tries to explain the essence of modern wars. Frank Hoffman defines hybrid warfare as "any adversary that simultaneously and adaptively employs a fused mix of conventional weapons, irregular tactics, terrorism and criminal behavior in the battle space to obtain their political objectives." (Hoffman, 2009) Another popular definition states that "hybrid threats simultaneously and adaptively employ a fused mix of conventional weapons, irregular tactics, weapons of mass destruction, terrorism, cyber-attacks, and criminal behavior, supported by a malicious information campaign.” (RAND, 2011) In turn, an expanded definition of Military Balance 2015, International Institute for Strategic Studies describes hybrid warfare as "sophisticated campaigns that combine low-level conventional and special operations; offensive cyber and space actions; and psychological operations that use social and traditional media to influence popular perception and international opinion." (IISS, 2015) Almost every attempt to define and reflect the "new" trends in warfare, seem to lead to confusion rather than clarity about the essence of the contemporary warfare.

In his recent article Murat Caliskan successfully outlines some of the key flaws in the "hybrid warfare" modern notion. He points out several deficiencies in the conceptualization of the hybrid warfare. Firstly, hybrid warfare is not new and hybridization is an inherent factor in the nature of all wars. Secondly, war is context-dependent and the degree and the manifestation of hybridity is related to the confrontation specificity. Thirdly, hybrid warfare is too broad concept, all wars could be easily labeled as hybrid wars. No matter whether a war is more irregular or more traditional in the means and methods employed, it is always conducted by statecraft for politics (Caliskan, 2018). Caliskan convincingly concludes that hybrid warfare is just another name for the neglected notion of grand strategy (Caliskan, 2018, p.18). Additionally, the means 
of war remain under-explored and under-specified by strategic theorists (Stones, 2013, pp.101-108), which today in turn is also a key source for misinterpretations of the hybrid warfare.

The main question is whether the hybrid war is a war or something different. Clausewitz formulated three basic criteria, which have to be met in order to a particular act to be qualified as a war: existence of violence, instrumental nature of the act and political attribution (Rid, 2012). Having in mind these three criteria, the main problem with understanding of the hybrid warfare as war is the political nature of the war, and that it must be attributed to a political entity at some point during the confrontation. History does not know acts of war without eventual attribution (Rid, 2012, p. 8). Hybrid war is not declared, it is hidden, it seeks to manipulate the perceptions, so that to be impossible to determine the moment of the beginning and (eventual) end of the aggression. Timothy Snyder states that the problem with phrasings in which the noun "war" is qualified by an adjective such as "hybrid" is that they sound like "war minus" when what they really mean is "war plus" (Snyder, 2018, p. 154). The hybrid war relies on combining, complementing and simultaneously applying, otherwise difficult-to-combine, instruments. Hybrid warfare has brought along opportunities for the implementation of more diverse instruments; the combination of different forms of war; the use of non-traditional actors; increasing the importance of the psychological aspects of the conflict, subversion and the impact on the peaceful population, etc. These transformations caused an amplification in the ambiguity surrounding the nature of the contemporary war. Having this in mind, the growing popularity of the term "hybrid warfare" is misinterpreted and related to the ambiguous boundaries between peace and war between state and non-state as well as to changes of the traditional actors and the elements of wars. But yet the change is not in the rules of war and its elements, but rather in the choice and the combination of the means applied. After the Cold War there was a tendency to treat each new manifestation of war as something suigeneris, rather than some variation on a common phenomenon (Stones, 2013, p.102). This brought to the forefront the discussion about whether the hybrid war is an act of war or something else. Hybrid warfare changes the strategic dynamic by dividing the military forms of war into elements whose employment may remain below the threshold of traditional war and synergizing those efforts with the coercive and destructive effects of non-military forms of war (Dayspring, 2015). "Hybridity" is found in the combination of the various political and violent means, and the synergistic effect of that combination produces a unique way to realize an end (Dayspring, 2015). Hybrid warfare is considered a form of warfare that includes conventional and nonconventional actions, carried out by regular, irregular or paramilitary armed forces and civilian forces through covert or overt actions, conducted in the entire spectrum of power elements (diplomatic, political, informational, cyber, economic, financial, military, legal etc.) in order to create ambiguity, targeting the vulnerabilities of the state that is subject to aggression. Although the bybrid warfare is pointed as a new way of aggression against the sovereignty and independence of a state (Savu, 2014), but it is not. Clausewitz stated that "Every age has its own kind of war, its own limiting conditions, and its own peculiar preconceptions." (Clausewitz, 2007, p. 240) The hybrid warfare, in its essence, is a war for limited political aims carried out by a variety of military and non-military means. As in any war, the strategy of this warfare aims to foster a sense of insecurity and uncertainty in the opponent. The main change is the emphasis on non-kinetic means, the combination of difficult to apply simultaneously instruments and the demand for a synergic effect. Hybrid warfare relies on disinformation, demoralization and division in society, political corruption, provocations and threats. Probably the most important instruments of the hybrid warfare are subversion, state-capture and disinformation.

Subversion is one of the leading instrument in conducting hybrid warfare. Subversion is the deliberate attempt to undermine the authority, the integrity, and the constitution of an established authority or order (Rid, 2012, p. 22). The main focus of subversive activities is on eroding social bonds, beliefs, and trust in the state and other collective entities (Rid, 2012, p. 22). The Subversive activities may be used within or 
without the framework of a larger kinetic operation (Hall, Assessing Military Thought-in Post Soviet Russia, 2019).

In turn, state-capture is usually referred to "a situation where powerful individuals, institutions, companies or groups within or outside a country use corruption to shape a nation's policies, legal environment and economy to benefit their own private interests" (Martini, 2014). State capture can broadly be understood as the disproportionate and unregulated influence of interest groups or decision-making processes, where special interest groups manage to bend state laws, policies and regulations through illicit practices (Martini, 2014). This notion of statecapture places emphasis on private entities as the primary abettors and perpetrator. In the context of the hybrid warfare, state-capture is not an activity of private groups, although they may be executors, but the main purpose focuses on certain interests of an adversary state that applies the hybrid warfare strategy to serve its own objectives. The main risk of state-capture is that the decisions of the political elite no longer take into consideration the public interest but instead favor a specific group (Martini, 2014), and in the case of the modern hybrid warfare - a specific state. Through the state-capture, the attacker-state tries to influence the victim state's political and economic processes. For example, by supporting and funding political parties and leaders, who subsequently express their gratitude by protecting the political and economic interests of the attacker. The key objective is the attainment of political and economic dependence by widespread corruption and political engineering.

Disinformation is an essential part of the strategy in almost every war, with the primary objective of demoralization of the enemy. The Communication Revolution transformed information operations into an Internet-enhanced phenomenon. The specific functions of the Web are a game changer. The interactivity and the possibility of free production of information content contributed to the appearance of the so called Internet trolls that focus on distraction and propaganda dissemination. The narrow-casting function and the asynchronous communication allow for the shaping of messages and the specific targeting of particular audiences. The almost complete lack of censorship and the free flow of information makes disinformation a fundamental non-kinetic tool in the hybrid warfare. The constant supply with disinformation serves for provocations, creation of sense of insecurity and stimulates the division of the victim state's society.

Technological progress and the globalization allow a more aggressive utilization of these non-military means to achieve (limited) political goals. Additionally, in the case of Central and Eastern Europe the turbulent transition from socialism was related to radical transformations of political and economic institutions, which in turn created conditions of instability and direct and indirect external (usually unhealthy) influences. Disinformation, subversion and state-capture are not new phenomena, but in the modern conditions they are often more interconnected, enhanced and are applied synchronously. Hybrid wars manage to mix more aggressively these non-kinetic means against a targeted state. Thus, modern hybrid war places a leading role on non-military means and does not use them only as additional and supportive tools for conventional military activities.

For the success of the hybrid warfare, vulnerabilities and enablers are needed. The analysis of them is crucial for the assessment of the degree of vulnerability. The specified factors are variables whose different weight depends on the relevant circumstances and the potential of the participants (the target and the attacker).

\section{METHODOLOGY}

\subsection{Discourse analysis}

More and more often today, objective reality is displaced by textuality; modes of production are supplanted by modes of information; representation blurs into simulation (Shapiro in: Derian, 1989, pp. ix- 
x). Discourse analysis addresses the questions of how knowledge, truth, and meaning are constituted. It poses a radical challenge to both the fact/value distinction and our concept of facticity. The question is how and where "meaning" resided in language - a question crucial to all those endeavors claiming to have some purchase on knowledge, truth, and fact. The fact's convincing appearance in the language, the discourse of the scientific objectivity and the relation of power and knowledge constitute "regimes of truth". (Shapiro in: Derian, 1989, pp. xiii-xv).

Every way of understanding international politics depends upon abstraction, representation, and interpretation. That is because 'the world' does not present itself to us in the form of ready-made categories or theories. Even the most 'objective' theory that claims to offer a perfect resemblance of things does not escape the need for interpretation (Bleiker 2001, pp. 509-533). The same is valid and for the concept of hybrid warfare and its manifestations. Therefore, the relationship between knowledge and power is important. While many say 'knowledge is power', this assumes they are synonymous rather than related. Discourse analysis is a critical attitude and approach that calls attention to the importance of representation, the relationship of power and knowledge, and the politics of identity in an understanding of global affairs. The application of discourse analysis on identity in international relations seeks to understand both the inner contours of the other and the diversity within one community - which groups, why and how they are marginalized; which participants have access to public discourse, and how to define themselves, which participants have access to decision making, and how this defines the other's images. Identity is important because every conversation/debate is related to identity, which is the reason why the hybrid warfare is so problematic because it is related to identity and cannot be easily confirmed or rejected. Moreover, discourse analysis sees language as the central social medium through which meaning is generated. To analyze policy decisions, we need to identify those 'key representations' (Hansen, 2006), speeches, texts, or points that structure the debates on a specific issue. It is not important whether the representations are true or false, but what the political implications of adopting a particular representation are. (Hansen in: Smith, Hadfield, Dunne, eds., 2012, pp. 102-103). It is also important how policy makers change their representations of the problem and of the policy as events unfold. There are two main routes for that. The first goes through pressure at the level of the discourse itself which comes from different domestic actors. The public defense of their representations and the decisions is more important than the decision making itself, or other organizational issues. The second route through which shifts are produced is through changes in the issue itself, some new data, or an accident, or international competence, etc. (Hansen in: Smith, Hadfield, Dunne, eds., 2012, pp. 101-106). When we want to understand what has happened in the past, the question is who wrote the story, not so much what was written. History is not as united and consistent as it is presented by the centers of power. Events get the status of real facts, not because they happened, but because someone remembered specific events. The question of what events will be remembered and how to memorize them is political. The possibility of progress and development is not denied, but the focus is on motives that are selfish, specific, and guide history along a specific trajectory. (Devetak in: Burchill, Linklater, eds., 2005).

In short, the text discusses the main debates and interpretations of the Bulgarian society on the role of Russia today. An attempt has been made to identify the dominant positions in the "talks" about Russia and to show the degree of vulnerability to hybrid attacks by Moscow. Some of the historical roots and their connection with today's debates and positions on Russia in Bulgarian society are traced. By applying discourse analysis, the main focus is on revealing the division of society and the influence of Russia on Bulgarian political life and the possibilities for hybrid intervention. This is set in a theoretical framework that traces the underlying enablers to hybrid vulnerability. 


\subsection{Theoretical framework}

The foundation for conducting hybrid warfare is the synchronized use of multiple instruments of power tailored to specific vulnerabilities across the full spectrum of societal functions to achieve synergistic effects (Cullen, P., \& Reichborn-Kjennerud, 2017). The vulnerability could be in any critical function (sector) of the state and thus give the "attacker-country" the opportunity to take advantage of the conditions and to exploit them, depending on the means at its disposal.

In the Bulgarian case there are many vulnerabilities and enablers which the Russian Federation can exploit. A group of Czech scientists Křriž, Bechná and Števkovoutlined points out six necessary conditions for a successful hybrid warfare (Jagello, 2000; 2016). Among them are:

- the attacked country has been mismanaged in the long term and it does not fulfill its basic functions;

- existence of division in the population;

- the potential attacker holds a certain attraction for a part of the attacked-country population and can therefore use soft-power instrument;

- the targeted country borders the attacker and is unable to effectively control its borders;

- the attacked state has no significant and reliable allies;

- the attacker has a certain degree of credibility in the international community, which allows him to influence the international community with his version of events (Jagello 2000, 2016).

The present analysis of the Bulgarian case allows for outlining two more additional enablers which are applicable for assessing the potential vulnerability to a hybrid warfare.

- Disputed historical past and relations between the two countries;

- A certain form of economic dependence.

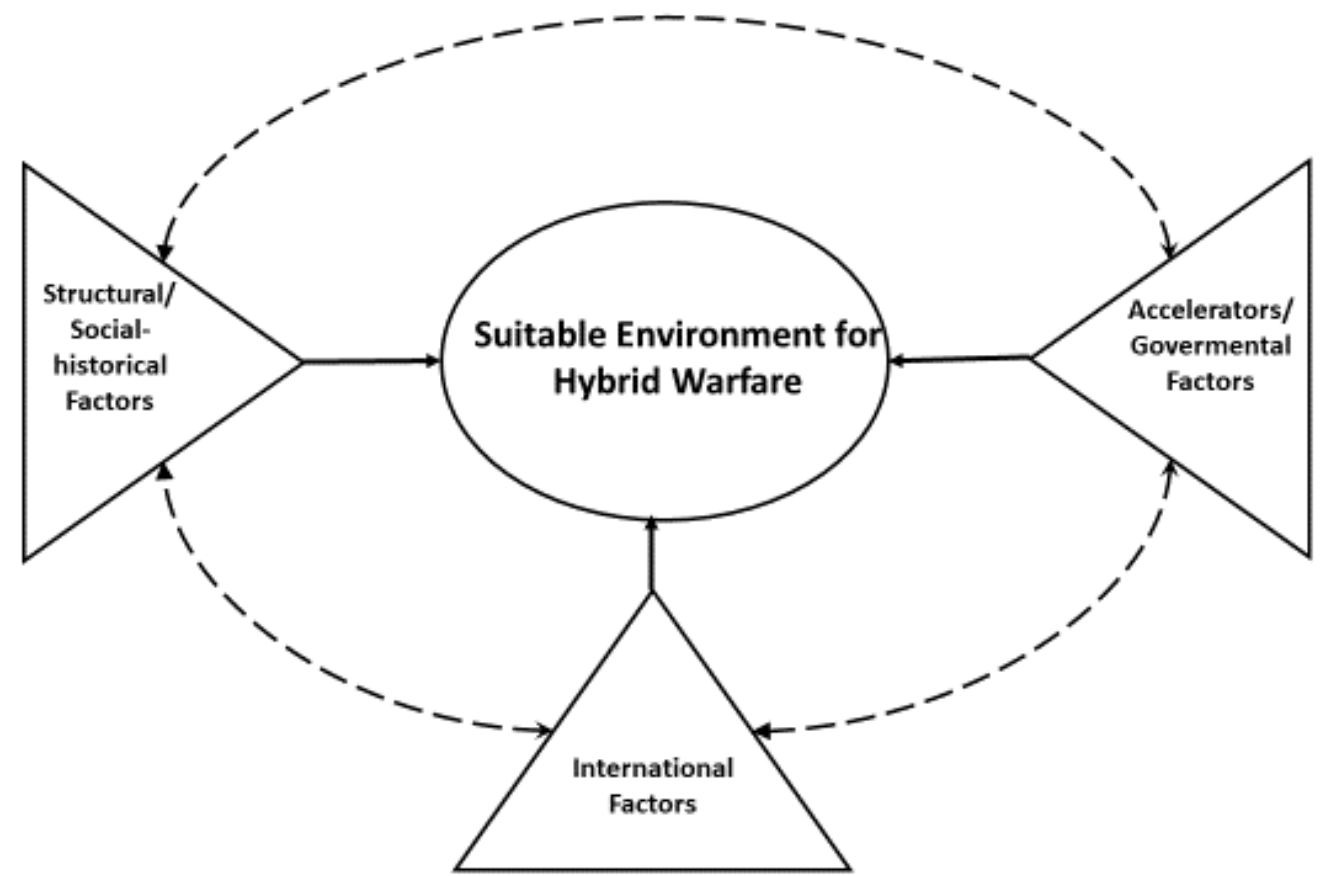

Figure 1. The Factors for Successful Hybrid Warfare

These eight criteria can be grouped into three main categories: socio-historical, governmental and international (see Figure 1). These eight enablers focus on the degree of the victim state's vulnerability, not on the success of a particular hybrid war. The existence of a single factor could be a source of vulnerability. Moreover, the existence of a single factor assumes the presence of others, which additionally complement and reinforce each other. These factors cannot be completely isolated from each other. 
Social-historical Factors. The category of socio-historical enablers represents the structural enablers for conducting a hybrid war. These perquisites are long-lasting, usually obvious, but they are nevertheless hard to change, and they are fundamental for a hybrid warfare. These root factors create the appropriate environment for implementing subversive hybrid actions.

Governmental Factors. The governmental prerequisites are accelerators for implementation of a hybrid warfare. This type of conditions is realized in the medium term, lead to a deterioration of the environment and the emergence of critical vulnerabilities. However, these catalysts are subject to control and elimination. Still, for this to happen an adequate assessment of the situation, a political will to act, and an availability of appropriate counter measures are required.

International Factors. These conditions are related to third countries and to the international community. Relations with third countries can lead to worsening or improving the conditions for a hybrid war. These enablers could be triggers for starting a hybrid war. The triggers appear surprisingly or in a short time period leading to a sharp escalation and a transformation in the dynamics of relationships. For example, if a country wants to enter a military alliance with other countries, this can provoke a third country to start a hybrid war to thwart it. On the other hand, international enablers could have a smoother and lasting impact. For example, it is extremely important for the great powers what kind of images they will be able to create in the face of the global community, especially in time of crises. In this kind of situations imposing a certain version of the events that led to the particular crisis may predetermine the final outcomes.

These are the several key factors, considered as a breeding ground for hybrid warfare. Each war is conducted in different contexts with different conditions. The presence of vulnerabilities and enablers predetermines the choice of means and their combination. These vulnerabilities are interrelated and have a different weights depending on the context. The theoretical framework, presented below, could be applied to many case studies with various victim states and attackers. In the case of Bulgaria there is a significant potential for becoming a target of a hybrid war. The Bulgarian politicians have problems in assessing hybrid threats in an adequate manner. That's why in the following paragraphs, these eight factors are applied to the Bulgarian case in order to assess the extent and the practical potential of Russian hybrid aggression.

\section{EMPIRICAL RESULTS AND DISCUSSION: THE VULNERABILITY OF BULGARIA TO HYBRID WARFARE}

\subsection{Social-historical factors}

The existence of a history with present-day implications is the first important structural enabler, because it creates the framework for the interpretation of events, policies and interactions. Bulgarian-Russian relations have a long history, filled with periods of contradiction and friendliness. The significance of Russian policy towards the liberation of Bulgaria as a result of the Russo-Turkish War (18771878) seemed to justify and demand Bulgarians eternal gratitude and closeness. The attitude towards Russia is considered an important part of the emotional and cultural background of the modern Bulgarian society. The problem is that the feeling of love and closeness is confronted with a sense of deceit and insincerity, due to the fact that in important historical moments (the unification of Bulgaria, the First Balkan War and the First World War), Russia is a major opponent of Bulgaria, not her protector.

After the Liberation of Bulgaria (1878) Russia has made constant efforts to control the political life and foreign policy of the country, provoking political turbulence, coups and violent changes to counter any attempt by the young Bulgarian state to break away from the Russian Empire's patronage. At the end of the Second World War, the invasion of Soviet troops in Bulgaria placed the state in the sphere of influence of the USSR. A number of reforms have been imposed on the political and economic system, and the 
establishment of the People's Court ${ }^{1}$ led to the execution of a large part of the political and military elite of the Kingdom of Bulgaria. Prison camps were built and aggressive repression measures were imposed against the opponents and the critiques of the new communist regime. These actions deepen the dividing line up to date - for a part of the Bulgarian society, Russia in the face of the USSR was a liberator of fascism and the Communist regime was successful, and for the other part the USSR was an invader who has forcefully imposed its corrupt Communist model. Gradually, the Bulgarian Communist elite turned Bulgaria into the closest ally of the USSR, placing Bulgaria's interests under the Soviet will. This process started from the very beginning. An example of this is the agreement by which the Bulgarian part of the geographic region Macedonia (the Pirin Macedonia, Blagoevgard region), should unite with the Yugoslavian part of Macedonia and to become a part of the Socialist Federal Republic of Yugoslavia. In addition, Bulgaria accepted teachers from Yugoslavia who began teaching the newly codified Macedonian language in schools in Pirin Macedonia and issued the order that the Bulgarians of the Blagoevgrad Region should claim a Macedonian identity. (Sygkelos, 2011, p. 156) Due to a rupture in the relations between Tito and Stalin this plan failed, but there was still an anti-Bulgarian policy, patronized by Moscow and pushed by the Bulgarian political elite led by Georgi Dimitrov. ${ }^{2}$

This line of close relationship remained during the Cold War. The highest expression of this was the wish of the Central Committee of the Bulgarian Communist Party to merge Bulgaria with the USSR and to transform the country into the 16th Soviet republic. Although this scenario was not realized, the real motives and the essence of this historical event also lead to a number of disputes and divisions in the contemporary Bulgarian society.

After the end of the Cold War, Bulgarian foreign policy has undergone a sharp turn. In the 1990s Bulgaria underwent a turbulent period of transformation and economic crisis. The membership in the EU and NATO had become a major foreign policy goal. In the first decade of the 21st century the accession to these organizations was realized. With NATO membership Bulgaria and Russia de facto have become opponents since Russia has been perceiving NATO as the "main external military danger". However, this does not change sharply the balance of Bulgaria's attitude towards Russia. Bulgarian society remains divided, as is its political elite. This late 19th century tendency for ambiguous attitude towards Russia's influence in Bulgaria is still a reality. The story repeats itself. Bulgarian-Russian relations today are placed in the context of the historical past, the current disagreements and the future relations between the two countries. The interpretations of the historical past create a major vulnerability and an appropriate ground for subversive hybrid activities.

The second factor is when the target country's population is divided along several dividing lines (Jagello 2000, 2016). The division reduces the resisting forces of society and the ability to recognize common threats. Usually, this kind of division is stimulated by the attacker through various provocations, which may vary across a wide range of national security issues (e.g. defense policy, alliance membership) to cultural-historical interpretations (e.g., provocative interpretation of history, etc.). The division of society contributes to the easier implementation of subversive activities, as well as to paralyze the function of the governmental institutions and of the political process as a whole. For the purposes of this study, we will illustrate the division into the Bulgarian society based on the opposition Russophiles and Russophobes. The twisted interpretations of the history directly lead to political bias about the objectives and the intentions of Russia before and today. The debate about the role of Russia, the "symbol Russia" is the most indicative of

${ }^{1} \mathrm{~A}$ special court of Communist Bulgaria established outside the operations of the constitutional frame of law.

${ }^{2}$ Georgi Dimitrov was the first communist president of Bulgaria, communist hero of the Reichstag Fire Trial and General Secretary of the Comintern. 
the division among Bulgarians. For many Bulgarians, Russia is a symbol of nostalgia, the lost communism of their youth and a source of empowerment and well-being. For others, Russia is the main culprit, who is responsible for the implementation of the brutal and repressive communist regime in Bulgaria with all the negative consequences of that. In the economic sphere, Russian supporters want more Russian energy projects because they actively proclaim that they are very profitable for the country and they endorse more associations with Russian (tourism, culture, military affairs etc.). The opposite group sees the energy projects as more dependency on Russia, that is to say more corruption and long-term economic losses; they are afraid of any relations with Russia and do not want to expand the Russian "diaspora" in the country.

Another sphere of clash is the previously mentioned mutual historical past. For some people Russia will always remain a brotherly Slavic state, a liberator and a defender of the Bulgarian interests. For others, Russia has always sought to subdue the Bulgarians and limit the Bulgarian progress through occupation, interference, and even wars. The division is also fueled by the provocative speeches of Russian and Bulgarian political elite, as well as by the insulting qualifications that the Russophiles and the Russophobes exchange. Thus, the boundaries between the groups become more and more visible, and the groups manage to preserve their positive self-image. The so-called tribal politics, or a policy that is not based on a set of political ideas but on an emotional loyalty to a group is also observed. Tribalism is an emotional tie that does not have any link to values, self-interest, or reason (Neack, 2018, p. 78). These tribal politics are benefiting some opportunists who, due to economic motives, turn into leaders and main advocates of the views of these "tribal" groups. In turn, this accelerates and deepens the division by reducing the possibilities for effective and direct communication. Further, the Russophobia/Russophilia group distinction is sharpen through subjective and emotional claims about the goodness of the in-group and the badness of the outgroup to distinguish why the in-group's vision is more reliable. The degree of division is also evident in the media, where pro-and anti-Russian biases and narratives can be clearly identified. The ancient principle "divide and conquer" is extremely relevant in the context of hybrid threats.

In the Bulgarian case, the dividing lines between Russophile and Russophobia is extremely evident when it comes to interpretations and positions towards certain historical events. In recent years, many topics which are "sacred" to the Bulgarians have been commented by Russian senior political and church representatives. These controversial statements have been perceived by a part of the Bulgarian society as a provocation. The effects of this vary, but in general, these remarks have succeeded not only in entering the mainstream public and media agenda but also in subduing it. This has caused annoyance in some and agreement in others, contradictory analyzes and comments. But ultimately, the result has been an emphasis on the ever-looming dividing line between Russophiles and Russophobes. Some of these "historical interpretations" are considered below.

In the contemporary history of Bulgaria there are not many historical events for which there is a common agreement and unity of the nation. Surely one of them is the Rescue of the Bulgarian Jews during the Second World War. Although it joins Tripartite pact, Bulgaria managed to prevent the deportation of the Jews from its territory. This is done through joint efforts of the Bulgarian Orthodox Church, the political elite and the people. In November 2017 a statement by Russian Foreign Ministry spokesman Maria Zaharova claimed that the Red Army had saved the Bulgarian Jews from deportation. This statement has provoked serious indignation and completely depreciated the historical feats of the Bulgarians, despite the fact that the statement came as a response to vandal acts against the Monument of the Soviet Army in Sofia. The very presence of this monument in the center of the capital is an accelerator for unceasing disputes and divisions into the Bulgarian society. The reference to the special merits of the Red Army has achieved at least two main objectives. The first one is the emphasis on the grandeur and moral resilience of the Soviet army. On the other hand, it has instigated public discussion about the role and importance of the USSR at the end of WWII and thus to stimulate a division in the Bulgarian society on the topic. 
Another more recent example is from the end of 2018 when the Russian ambassador to Bulgaria gave on behalf of Russia a "New Year tree". An event that is, at first glance, something normal. In fact, however, the "New Year tree" itself created a fertile ground for a new cycle of discussions about Moscow's true intentions. The problem comes in two dimensions. The first is the overall appearance of the gift, giving rise to references to the Soviet past - the tree was called "New Year", not Christmas, and it was decorated with numerous large red stars. The second issue had a serious historic burden and it was related to the place where the tree was located. In 1925, Bulgarian Communists, instructed and supported by Moscow, committed the largest terrorist attack in Bulgaria, killing 213 people and injuring more than 500 in the "St. Nedelya" Cathedral (Dikov, 2015). It is in the square in front of the church that the "New Year" tree was placed. This seemingly ordinary gift has caused a series of comments and once again stimulates division into society. For some, the tree is a mockery of Bulgarian history and memory, and for others it is just a wonderful symbol of Bulgarian-Russian friendship. For some, it is a provocation, for others it is a rapprochement.

As noted, the historical past of the two countries is a milestone in their modern relations. The different interpretations of history lead to the reaffirmation of the Russophile-Russofobes division. This is a huge enabler for arising a serious vulnerability, subversion and diversion.

The third enabler requires the potential attacker to hold a certain attraction for a part of the attacked-country population and to be able to therefore use soft-power instrument (Jagello 2000, 2016). This facilitates the dissemination of disinformation and the implementation of subversive activities. The main target of the hybrid warfare is the perceptions of the population of the attacked state. Through subversive activities and information operations, the attacking state aims to strengthen its influence on the domestic politics. These activities have a strong potential for impact in Bulgaria. As mentioned above, a large segment of the Bulgarian population has a positive attitude towards Russia. In 2018, Alpha Research sociological survey shows that $56 \%$ of the Bulgarians have a positive attitude towards Russia. It is important to note that this percentage is lower than in previous surveys in which the positive attitude is expressed by over 65\% of the Bulgarians (Alpha Research, 2018 ). In general, especially the older segments of the population tend to have a positive attitude towards Russia. There are a number of movements in the country and NGOs expressing their extreme (even fanatic) support for Russia (The National Movement of "Russophiles", The Bulgarian Eurasian Center, etc.).

Moreover, a significant part of the political elite, as well as leading parliamentary parties, clearly express a Russophile bias on their political platforms and actions. For them modern Russia is an alternative of the "corrupted" and "false-hearted" Western-led international order, a savior of Slavicity, the Third Rome (the defender of Orthodox Christian Church), a symbol of an iron hand, political power, order and traditional patriarchal values. From the point of view of a hybrid threat protection, it is extremely important for the state to prevent systematically the infiltration of political leadership of persons associated with a potential hybrid striker. And also, to enhance the loyalty of the citizens to the state (Jagello 2000, 2016). On the contrary, there are groups in Bulgaria that clearly declare their loyalty to Russia and Russian interests, and a significant part of the political elite with their actions and speeches demonstrate dependence on Moscow. This is due to the fact that before 1989 a large part of this political elite, including key figures from the executive and the legislature, was part of the repressive state security structures (the Bulgarian version of the Soviet security services) protecting the communist regime in Bulgaria. That is why there are serious doubts that these people are politically, financially dependent and controlled by the Kremlin.

In this context it's especially important to emphasize that hybrid warfare is in the first place an information war. Nowadays media and social media in particular are the most effective manipulation instrument. Nevertheless, fake news is only the tip of the iceberg in the ocean of psychological warfare (Naydenov, Bulgaria Analytica, 2017a) In the relations between the countries it is very important how they define each other in the public domain. And when words such as "enemy", "aggression", "war", etc. are 
used, it signals that the information environment is being influenced by foreign information strategies. In the Bulgarian case one of these visible influences is that of Russia and that is presented in a research, carried out by Dimitar Vatsov and Milena Iakimova. They have tried to reveal the actual scope of the disinformation and fake news dissemination in the country. In 2015 some Bulgarian researchers in the social and human sciences were struck by the rise of anti-liberal discourse in Bulgaria (Vatsov \& Iakimova, 2017). At that time this discourse co-opts grassroots criticism of liberalism and globalization, recasting both left and right populism in nationalist terms. Bulgaria was not an exception. The semantic analysis of this study indicates that the Russian narratives have significant influence over the Bulgarian media. The number of publications supporting the official Russian thesis about Crimea and Ukraine in 2013 was 56 (all of them at the very end of the year, after the beginning of the Euromaidan protests). Then grew to 6,109 in 2016 (Vatsov \& Iakimova, 2017).

In 2013, the Bulgarian media made no mention of 'Russia's enemies', even though the EU and NATO had long since expanded and reached almost their present extents (they found just 54 publications). In 2016, however, phrases such as 'enemies of Russia', 'aggression against Russia', and 'war against Russia' were found in 7,511 publications. The number of articles praising Russian weapons rose from 22 (in 2013) to 745 (in 2016), while articles praising Russia in general soared from 44 to 1,326 (Vatsov \& Iakimova, 2017).

One of the conclusions of this analysis is that Russian-friendly propositions were introduced intensively into the Bulgarian media sphere at the end of 2013 (after the beginning of the Euromaidan protests), and especially in March 2014 (with the Crimea Crisis). The talking point promoted in the highest number of publications is that Russia is a victim of aggression by the West. Additionally, the data also show that the two practical-political statements of the official Russian position - Krym nash (Crimea is ours) and 'the Euromaidan was a putsch orchestrated by the West - as well as the proposition that the Western sanctions are unjust were promoted by a significant number of articles, which saw the most sustained and steepest growth from 2014 to the end of 2016 (Vatsov \& Iakimova, 2017).

Concerning the domestic affairs, the study shows that the information environment for the election of Bulgaria's new president, Rumen Radev, was shaped in appropriate way. The indicator for such a conclusion was the increasing number of favorable publications, corresponding to the official Russian positions in foreign and energy policies. His election campaign was largely based on such talking points:

- 'Crimea is de facto Russian',

- 'the sanctions against Russia must be lifted',

- 'Bulgarian foreign policy must be made in Sofia [not in Brussels].

The promotion of these ideas has been made possible by the assistance of journalists, the media, politicians and public figures who identify themselves as Russophiles. That is why the suspicions that Russia has been systematically interfering in the internal political process in Bulgaria are growing. The analysis shows the existence of a Russian subversive strategies that are close to the political processes in Bulgaria. Some experts explicitly point out the Russian attempts to interfere with the presidential elections in Bulgaria in 2016 (Naydenov, Bulgaria Analytica, 2017a).

Another aspect of the impact of Russian-oriented media information is the linguistic framing of the opponents of Russian positions in Bulgaria. This part of Bulgarian civil society, which opposes close ties with Russia is systematically discredited and disparaged by labeling them as "tolerasts", "grant-spongers", "liberal fascists", and "Western lashes". These labels are turned into convenient titles mocking political opponents (Vatsov \& Iakimova, 2017).

The presented information strategy is expansive and usually successful. By using questionable historical analogies; constructing an image of a victim; and introducing controversial arguments about the right to have privileged interests in the countries of the former Eastern Bloc, are just some of the messages that are imposed as truth. The problem with the spread of such deliberate narratives is the so-called "illusion of 
truth". Essentially, people tend to rate items they've seen before as more likely to be true, regardless of whether they are true or not, and seemingly for the sole reason that they are more familiar. This does not mean that truth will be superseded by untruth, but that untruth itself is more likely to be judged to be more true, depending on the more often we meet it (Stafford, 2016). In this way, the source of disinformation manages to make its statements more receptive to a wider circle of people and to stimulate division into society. This is more valid in the absence of a coherent policy of countering disinformation through educational activities and cooperation with the media and the authentic civil society.

\subsection{Governmental factors}

The fourth overall factor is when the attacked country has been mismanaged in a long term and it does not fulfill its basic functions (Jagello 2000, 2016). The presence of this enabler facilitates state-capture and makes the country an easy target for subversion. In 2017, Bulgaria is ranked 33rd in Europe by GDP per capita (Statistctimes, 2018) and occupies the last place in the EU by the same indicator (Europa.eu, 2018). There is also serious political instability, and since the beginning of the 21 century Bulgaria has had 9 different governments. But the change of governments has not lead to a real political leadership change, but rather to a concentration of economic and political power, corruption and limitation of media freedom. The level of corruption is also high, as the Corruption Perception Index puts Bulgaria at 71 st place out of 180 countries (Transperancy International, 2018). The World Press Freedom Index places the country on 111th position (out of 180), which is a clear warning that in Bulgaria exist poor governance and lack of transparency (Reporters without Boarders, 2018). Moreover, the Democracy Index puts Bulgaria at 47th place in the category of "flawed democracy", which shows that the state has immature democratic institutions (Economist, 2018). In addition, the infrastructure and the basic public services such as health and education also lag significantly behind the EU average. Statistics can be supplemented by other indicators, but in general they all confirm the problematic governance of the country. Therefore, this is a root-cause for many vulnerabilities, which could be exploited by foreign subversive interventions. In sum, the lack of effective institutions and ability to identify and recognize the actual conduct of a hybrid war on Bulgarian soil is a key vulnerability.

The fifth factor requires the presence of tangible dependence. This factor deprives the political leadership of freedom of action and reveals opportunities for subversive activities and state-capture. This analysis highlights Bulgaria's energy and security dependence on Russia as an extremely important factors which has its multidimensional implications. The energy dependence is related to severe state mismanagement and the so called "state capture". The core of the hybrid warfare is the combination of various means, the creation of ambiguity and the permanent (though shifting) pressure. Therefore, it is not surprising that Russia is using its energy potential as a major means of impact. The Kremlin is accused of using the energy card as an exchange coin for adherence to Moscow's political line. Critics of Russian politics point out that Russian energy projects lead to substantial long-term financial losses as well as to unhealthy dependence on Moscow (Naydenov, Bulgaria Analytica, 2017). As was mention above, in Bulgaria one of the main political and economic dividing lines is the question of "more" or "less" Russian energy projects.

Russia's critics link its energy projects with long-term negative consequences and political dependence. As unprofitable energy projects they point out Belene nuclear power plant construction and the possible passage of a second Russian gas pipeline through the country. From this point of view, the problem with Russian projects is that they bind both countries over the long term and enable subversive interference in domestic and foreign policy. And this happens under controversial economic parameters and vague benefits. In other words, energy projects are above all a means of "disguised" achievement of policy goals, a tool of pressure and dependency, due to the lack of diversification (Naydenov, Bulgaria Analytica, 2017). The way 
Russia uses the gas prices as an instrument for exercising pressure on Ukraine is an example of that potential vulnerability for hybrid warfare. The Bulgarian proclamations for reduction of the energy dependence have only limited results. Therefore, the energy sphere is a vulnerability that can be exploited for further pressure and political and economic subversion.

Another key area of dependence is related to the imperative modernization of the Bulgarian army. Due to the still ongoing process of modernization, the combat capabilities of the Bulgarian armed forces are far from those of a potent NATO member. This creates a serious vulnerability for foreign subversive activities. There is a clash of interests and an attempt to influence the political process of purchasing new arms or repairing old Soviet machinery. The main clash expressed in the public sources is about to what point the life extension of the old Soviet weaponry is profitable. For some of the proclaimed views, this is the cheapest option guaranteeing military capabilities. The opposite public position defends the opinion that this is just a provocative attempt to move Bulgaria away from NATO standards and anchor the state into the Russian sphere of influence, for others. The prolongation of the Bulgarian Army's dependence on Russian military equipment maintenance creates a vulnerability with huge potential for interference and exploitation. This may lead to the execution of controlled pressure and may reduce the potential for conducting an independent foreign policy and the protection of the national security. In short, the slow process of modernization creates vulnerabilities to subversive strategies.

A prominent example is the maintenance of obsolete Mig-29 jets left over from the Cold War. The economic difficulties and the lack of a strategic vision and will in the government are key factors for the problems of ensuring national security by an efficient Bulgarian army. The country's decision-making for the purchase of new military equipment for land, naval and air force has been slowed and multiple governments are unable to pick and stick to their choice for supplier. The country still has to rely on old Soviet military equipment, which is not always compatible with the equipment of other NATO members. In summary, the difficult process of the modernization of the armed forces has become a major battlefield and vulnerability for subversion and hybrid pressure.

\subsection{International factors}

The sixth factor is when the attacked country borders the attacker and is unable to effectively control its borders (Jagello 2000, 2016). This factor allows an attacker to exert pressure by threatening with direct military conflict or by using irregular military forces ("the little green men"). Bulgaria has no land border with Russia, but both countries have access to the Black Sea. The Crimea annexation, the precarious future and the possible militarization of the Black Sea pose serious risks for Bulgarian national security. The state and the preparedness of the Bulgarian army is unsatisfactory, and it can hardly prevent a possible attack against the country. There are material and financial constraints as well as an overall necessity for modernization. In addition, the dependence of the Bulgarian combat capabilities on the old Soviet arms is strong. Although serious efforts are currently being undertaken to modernize the Bulgarian armed forces, the process is slow, contradictory and politicized. This is a key vulnerability and also one of the main topics in the modern relations between Bulgaria and Russia, which will be addressed later.

The seventh factor appears when the attacked country has no dependable allies (Jagello 2000, 2016). The presence of allies can serve as a deterrent against escalation of conflict. Bulgaria is a member of NATO and the EU, which greatly enhances its resistance to a possible (hybrid) threat. The Bulgarian state relies on its NATO membership as a guarantee of its national security and territorial sovereignty. In addition, Bulgaria maintains good relations with its neighbors. During the Bulgarian Presidency of the EU in 2018, the Bulgarian government put the European future of the Western Balkans as a key priority and confirmed that the European integration of the region is the country main interest. Overall, thanks to its membership 
in the EU and NATO, the Bulgarian government is able to find support in case of possible external threat to the national security.

The eighth factor exists when the attacker has a certain degree of credibility in the international community, which allows him to influence the international community with his version of the events (Jagello 2000, 2016). This enabler allows manipulation of the information environment and thus the subversive activities could remain hidden or denied. Russia is exerting efforts successfully to present its point of view especially in the countries of the former USSR and Eastern Europe. The basis for the successful presentation of Russian narratives is the conduct of information operations and the exploitation of the opportunities provided by the Web. Russia is able to take advantage of free access, narrowcasting, lack of censorship and other Internet features to present and defend its image and positions. This is particularly true for the former Eastern Bloc countries, where large segments of the population have a positive attitude towards Moscow. A recent research by RAND Cooperation showed that Russia is engaged in an active, worldwide propaganda campaign. As part of this campaign, Russia disseminates propaganda to Russian speakers in the Baltics, Ukraine, and other nearby states through a variety of means, including traditional and social media (Helmus \& al., 2018). Also according to this study Russia is engaged in an aggressive propaganda campaign aimed at multiple different national audiences to include its nearabroad neighbors on its western border. Russia appears to actively synchronize social media products with those of various other information outlets, including Russian branded TV broadcasts and web news, proxy civil society agencies, and web outlets (Helmus \& al., 2018).

One of the dominant positions explaining Russian behavior emphasizes the claims that Russian propaganda has managed to unify the extreme left and the extreme right stands as well as the dissatisfaction among large segments of the world audience, thanks to the global virtual space. Moreover, the Kremlin's information campaigns stimulate nationalism in the Western world and undermine the resilience of "Western civilization". This contributes to the formation of an atmosphere of mistrust towards the EU and NATO. Moreover, Russia tries hard skillfully to build a self-image of an underprivileged victim of "Western aggression"; a target of disinformation; and a viable alternative to the current global decline. In addition, to reinforce its position, Moscow uses historical analogies, comparing the current policies of Western nations with that of Napoleon and Hitler's aggressive actions against Russia. The self-image of a strong peacemaker, fighting the evil in the world, is an important component of the Russian communication strategy.

Other key propositions that Moscow is trying to impose on the global agenda are that Russia deserves and has the moral and lawful right to restore its sphere of influence in the post-Soviet space. The Kremlin wishes its interests in these countries to be respected and calls for recognition of its privileged interest there, which in fact is a key principle underlying Russian foreign policy. Russia declares willingness and the right to protect these interests with all the necessary means. Moreover, The Kremlin imposes its self-image of a recovering great power without whose cooperation the problems in the world cannot be solved. All these positions find support (even limited) both on the left and on the right, and for many in the post-Soviet space (including Eastern and Central Europe) they sound trustworthy and viable. This is because the stories are skillfully framed to sound plausible and to be in line with the preconceptions of certain target audiences. These segments are characterized by emotional ties with Russia and the implacability towards facts and arguments challenging the truthfulness of these Russian claims.

\section{CONCLUSION}

Promoting hybrid warfare as a strategy has led to the transformation of this concept into a basic framework for interpreting Russian relations with many countries in the world, especially after the events in Ukraine and the Crimean annexation. Eventually hybrid war is a convenient "tool" applied by other 
countries as well. In this case, whether Russia applies a hybrid strategy against Bulgaria is a matter of discussion. The accusations against Moscow may sound paranoid, but they are often linked to serious proofs. The present paper outlined a model which contents the basic prerequisites for conducting a hybrid warfare. The model allows assessing the vulnerability from hybrid subversion. These factors are largely due to the internal characteristics and problems of the (Bulgarian) state. Together in the context of specific relationships with regional and global powers, the highlighted indicators show that there are sufficient vulnerabilities that can be exploited by hybrid threats. Russia as a global power with its economic, financial and political influence, has been able to influence the internal processes of many countries in Eastern Europe. Therefore, Russian-Bulgarian relations will continue to be controversial, especially on the background of the intensifying international tension and the internal disagreements.

\section{REFERENCES}

Alpha Research. (March 2018). Public Attitudes March 2018. Retrieved from https://alpharesearch.bg/search/?title $=$ March +2018

Bleiker, R. (2001). The Aesthetic Turn in International Political Theory, Millennium: Journal of International Studies, 30(3), 509-533.

Caliskan, M. (2018). Hybrid warfare through the lens of strategic. Defence \& Security Analysis, 35, 140-58.

Clausewitz, C. v. (2007). On War, Translated by Michael Howard, Peter Paret. Oxford University Press.

Cullen, P., \& Reichborn-Kjennerud, E. (2017, January). Understanding Hybrid Warfare. Retrieved from https://assets.publishing.service.gov.uk/government/uploads/system/uploads/attachment_data/file/64777 6/dar_mcdc_hybrid_warfare.pdf

Dayspring, S. (2015). Toward a Theory of Hybrid Warfare: the Russian Conduct of War During Peace. Retrieved from https://calhoun.nps.edu/bitstream/handle/10945/47931/15Dec Dayspring Stephen.pdf?sequence=1\&isAl lowed =y

Derian, J. D., \& Shapiro, M. (1998). International/ Intertextual Relations. Postmodern Readings of World Politics. New York: Lexington Books.

Devetak, R. (2005). "Postmodernism." In Burchill, S. \& Linklater, A. Theories of International Relations. London: Palgrave, 161-187.

Dikov, I. (2015, April 15). Archaeology in Bulgaria. Retrieved from http://archaeologyinbulgaria.com/2015/04/16/bulgaria-marks-90-years-since-horrific-communist-terroristattack-in-st-nedelya-cathedral-in-sofia/

Economist. (2018). The Economist Intelligence Unit's Democracy Index. Retrieved from https://infographics.economist.com/2018/DemocracyIndex/

Europa.eu. (2018). Living in the EU. Retrieved from https://europa.eu/european-union/about-eu/figures/living en

Hansen, L. (2006). Security as Practice: Discourse Analysis and the Bosnian War. London: Routledge.

Hansen, L. (2012). “Discourse Analysis, Post-structuralism, and Foreign Policy.” In Smith, S., Hadfield, A., Dunne, T. Foreign Policy. Theories, Actors, Cases. Oxford Press: Oxford, 94-109.

Hall, J. (2019, February 4). Assessing Military Thought-in Post-Soviet Russia. Retrieved from https://divergentoptions.org/2019/02/04/assessing-military-thought-in-post-soviet-russia/

Helmus, T. C., \& al., e. (2018). Russia Social Media Influence. Santa Monica: RAND Corporation.

Hoffman, F. (2009, Ocotober 1). Hybrid vs. compound war. Retrieved from http://armedforcesjournal.com/hybrid-vscompound-war/

Jagello 2000. (2016). Hybrid Warfare: A New Phenomenon in Europe's Security Environment, 2nd Edition. Retrieved from http://data.idnes.cz/soubory/na_knihovna/A161212_M02_029_HH16_PP-EN-V1.PDF

Martini, M. (2014, March 11). Transparency International, State Caputre: An Overview. Retrieved from https://www.transparency.org/files/content/corruptionqas/State_capture_an_overview_2014.pdf

Naydenov, M. (2017, December 14). Hybrid War as a Challenge to the National Security of Bulgaria. Retrieved from: http://bulgariaanalytica.org/en/2017/12/14/hybrid-war-as-a-challenge-to-the-national-security-of-bulgaria/ 
Naydenov, M. (2017a, November 3). The Russian Subversion of the Defense System of Bulgaria - an Enabler for "State Capture". Retrieved from: http://bulgariaanalytica.org/en/2017/11/03/russian-subversion-of-the-defense-system-ofbulgaria-an-enabler-for-state-capture/

Neack, L. (2018). Studying Foreign Policy Comparatively: Cases and Analysis. London: Rowman \& Littlefield Publishers.

RAND. (2011). Preparing for "Hybrid" Opponents. Santa Monica: RAND Corporation. Retrieved from https://www.rand.org/pubs/research_briefs/RB9620/index1.html\#fn1

Reporters without Boarders. (2018). 2018 World Press Freedom Index. Retrieved from https://rsf.org/en/ranking

Rid, T. (2012). Cyber War Will Not Take Place. Journal of Strategic Studies, 1, 5-32.

Savu, G. (2014). Hybrid Warfare - Ways of Manifestation and Counteraction from Euro-Atlantic Perspective. EuroAtlantic Connections, 88-99.

Snyder, T. (2018). The Road of Unfreedom. New York: Penguin Random House.

Stafford, T. (2016, October 26). How Liars Create the 'Illusion of Truth'. Retrieved from http://www.bbc.com/future/story/20161026-how-liars-create-the-illusion-oftruth?ocid $=$ ww.social.link.facebook

Statistctimes. (2018). Retrieved from http://statisticstimes.com/economy/european-countries-by-gdp-per-capita.php Stones, J. (2013,). Cyber War Will Take Place. Journal of Strategic Studies, 36, 101-108.

Studies, I. I. (2015). Military Balance. London: IISS.

Sygkelos, Y. (2011). Nationalism from the Left: The Bulgarian Communist Party During the Second World War and the Early Post-War Years. Leiden: BRILL.

Transperancy International. (2018). Transperancy International - Bulgaria. Retrieved from https://www.transparency.org/country/BGR

Vatsov, D., \& Iakimova, M. (2017, October 27). Co-opting discontent: Russian propaganda in the Bulgarian media Retrieved from https://www.stopfake.org/en/co-opting-discontent-russian-propaganda-in-the-bulgarianmedia/ 